Che arl Beck Papers

in Russian \&

East European Studies

Number 1303

Deborah L. Pearl

Tales of Revolution:

Workers and Propaganda Skazki in the Late Nineteenth Century 
Deborah L. Pearl is Associate Professor of History at Cleveland State University. She received her Ph.D. from the University of California, Berkeley. Her research focuses on workers and the Russian revolutionary movement in the late nineteenth century. Dr. Pearl's recent articles include "Tsar and Religion in Russian Revolutionary Propaganda" (Russian History, 1993) and "From Worker to Revolutionary: The Making of Worker Narodovol'tsy" (Russian History, 1996).

No. 1303, August 1998

1998 by The Center for Russian and East European Studies, a program of the University Center for International Studies, University of Pittsburgh

ISSN 0889-275X

The Carl Beck Papers

Editors: William Chase, Bob Donnorummo, Ronald H. Linden Managing Editor: Eileen L. O'Malley

Cover design: Mike Savitski

Submissions to The Carl Beck Papers are welcome. Manuscripts must be in English, doublespaced throughout, and less than 120 pages in length. Acceptance is based on anonymous review. Mail submissions to: Editor, The Carl Beck Papers, Center for Russian and East European Studies, 4G-17 Forbes Quadrangle, University of Pittsburgh, Pittsburgh, PA 15260. 
The dawning of radical consciousness is a key episode in the published autobiographies of Russian worker-revolutionaries. Frequently, this moment of epiphany is linked with the reading of some work of underground, illegal literature. Such is the case with Petr Moiseenko, an active participant in the revolutionary and labor movements from the 1870 s, best known as one of the instigators of the Morozov strike of 1885. In his Memoirs of an Old Revolutionary he states at the outset: "I must begin my memoirs from the time when illegal brochures first came my way: 'The Tale of Four Brothers,' 'The Clever Trick,' 'The Tale of a Kopeck,' and the 'Revolutionary Songbook.' From that time my awakening from the old, religious teachings began."

Moiseenko was at that time a young weaver at a provincial textile factory. A friend's brother apparently obtained these booklets at the fair in Nizhnii Novgorod. As Moiseenko and his friend began to study them, their disbelief grew: the contents seemed to be truthful, yet were so at variance with what they had been taught. Since the two young men were "quite religious," they sought clarification at a nearby monastery, an adventure which only led to further disillusionment and, as Moiseenko tells it, loss of faith. What were these booklets, and what role did they play in the revolutionary movement? How could "tales" like those named above, published anonymously and illegally, become a catalyst for a complete rethinking of received beliefs or even lead a young worker to embark on the path of revolution?

Various kinds of literature were used in propaganda among workers by participants in the Russian revolutionary movement of the late nineteenth century: socalled belletristika (works of fiction) by popular Russian authors; articles from the "thick" journals; specially composed stories and expositions of political economy in the form of pamphlets; songs and poems; foreign literature in translation. These works served both as vehicles for the transmission and spread of radical ideals to workers and as a means of communication between members of two disparate social groups: radicals from the educated classes and urban workers. This body of literature in the service of revolution remains an underexploited resource in our efforts to understand the revolutionary movement and its significance for workers in the 
Russian Empire. Titles of some of the most popular works strike a familiar chord for scholars in the field, but to date little has been done to examine in detail their content, context, function, and meaning. The discussion that follows will present some general findings on the use of this literature as it relates to workers and then focus on one intriguing genre noted by Moiseenko: the revolutionary skazka or tale modeled on the traditional folktale but with a revolutionary content and moral. A complete translation of the Tale of Four Brothers, a perennial favorite with both workers and propagandists, is provided in the appendix. ${ }^{2}$

Propaganda literature was closely linked with the key institution of the revolutionary movement in the workers' milieu, the workers' circle (kruzhok). Circle members read and discussed these works, guided by the explanation presented by the propagandist, who was typically a student or other member of the intelligentsia. The oral element of propaganda and the ensuing interchange of ideas were of key importance; sometimes the propagandist read works aloud, or retold them. Both legally published and illegal "underground" works were used in propaganda among workers. Circle studies among newly recruited workers often began with legal works, which could be passed off as harmless and merely educational. Once workers had gained political "consciousness" and proved trustworthy, they were given illegal works to read. Some propagandists felt strongly that illegal literature should be used quite sparingly and avoided where possible. The evidence shows, however, that illegal works did circulate both within and outside the confines of the kruzhok, obtained from coworkers and in other ways.

Revolutionary propaganda activity was not a one-way street, with ideas transmitted in a top-down fashion from intelligenty propagandists to workers. Relations between the two social groups involved in the movement were complex and characterized by mutual influences. While the vast majority of works intended for propaganda were indeed written by educated radicals from the intelligentsia, they were not always successful with their intended worker audience. Archival and other sources provide good information on the composition, publication, and distribution of illegal literature and on the number and size of editions. Specific works are 
frequently mentioned in memoirs and police reports, and illegal works seized during arrests were noted in judicial records. We can thus determine the relative popularity of different works. Some withstood the test of time over decades; others proved ephemeral. In this way, workers' reactions validated and influenced the propagandists' choice of material and presentation. A second important issue is how the material was received: the transmission of ideas is not mechanical, obvious, or singular. A particular work of propaganda literature might be interpreted by workers in ways not intended by the author. (And there might be more than one possible interpretation.) To quote Roger Chartier, who has offered thought-provoking interpretations of popular literature in early modern France: "the diffusion of ideas cannot be held to be a simple imposition. Reception always involves appropriation, which transforms, reformulates, and exceeds what it receives. Opinion is in no way a receptacle, nor is it soft wax to be written upon. The circulation of thoughts or cultural models is always a dynamic and creative process. Texts . . . do not bear within them a stable and universal meaning, and their migrations within a given society produce interpretations that are mobile, plural, and even contradictory."

One factor influencing workers' reception of this literature, and one perhaps not considered by the propagandists, was the context in which workers first learned of or read (or heard) these works. As noted above, workers who left memoir accounts frequently linked the moment of their intellectual awakening to some such work. Illegal works differed from the legal works to which workers were also exposed in the circles in several very basic ways. Freed from the strictures of censorship, this literature could bluntly expose and criticize the existing social and political order, not sparing the upper classes, the church, even the tsar himself; it could call for revolution and describe the desired socialist society. As illegal works, with harsh penalties attached for possession, they often held the allure of the forbidden, creating bonds of conspiratorial comradeship between those who read and passed them on. Some workers seem to have perceived these works as containing secret knowledge that would shed light on the reasons for their harsh existence and answer the question of what could be done. One worker writes that as a teenage 
worker at a Moscow factory in the mid-1890s he began reading some works of legal but "tendentious" literature with other young workers: "We heard that there were still other books-underground, uncensored, in which was written the whole truth about workers and which showed workers what it was necessary to do to improve their situation. We very much wanted to read such books; although we knew that people were imprisoned and persecuted for them, we searched for them everywhere." Some time later, a radical worker was hired at the factory. After some months, having sworn them to secrecy, he assembled ten or so of the young workers in the cemetery (a setting that no doubt heightened their sense of the fateful nature of the gathering) on a Sunday morning; "and for the first time we heard underground books. . . . We, holding our breath and with sinking hearts, heard these pamphlets; we were fearful, but at the same time we understood the real truth." The meeting continued until evening: "After that our eyes were opened and we began to think about things in a new way. ${ }^{4}$ A number of similar examples could be given. To some extent, it does not appear to matter which work of illegal literature workers heard or read; the first such contact made an indelible impression. The booklet itself sometimes seems to be a talismanic object. ${ }^{5}$

One distinctive genre of propaganda literature was the revolutionary skazka or tale, modeled after the traditional folktale, but with a didactic purpose and a revolutionary moral. These pamphlets bore colorful titles that conjured up tales of the supernatural, the wisdom of popular sayings, or the sacred truth of religious tracts: The Clever Trick, The Tale of a Kopeck, Out of the Frying Pan into the Fire, On Truth and Falsehood. The best known of this genre, including those mentioned above, date from the 1870s and are part of a group of pamphlets associated with the peasant-oriented populism of that period, beginning with the Chaikovsky circle and encompassing the movement "to the people." They were composed in the early to mid-1870s and first printed on the presses of revolutionary groups at the time: the Chaikovsky circle and Rabotnik presses in Geneva, the Vpered! presses in London and Zurich. The selection of the skazka form reveals some assumptions about the type of literature that would appeal to the Russian peasant or member of the narod: 
the brochures resemble the type of cheap, lubochnaia literature with which they were already familiar. ${ }^{6}$ These were narrative works, they told a story (largely through dialogue or conversation), and the language was a "folksy," presumed peasant style, frequently studded with sayings and popular idioms. Were peasants in fact the audience for these works? We must keep in mind that revolutionary populists of the 1870 s did not make a clear distinction between peasants and urban workers. Although they envisioned their audience as a peasant one, populists carried on significant propaganda among urban workers in the 1870s, and this did not contradict their conception of the narod, the lower-class working people as a whole. Urban workers were viewed as members of the narod who were temporarily living and working in the city. The Clever Trick, arguably the most famous of these tales, seems geared to this particular contingent of the popular whole, beginning with the words, "There's a fellow at our factory . . . ."7

Some of these skazki continued to circulate and provoke discussion in kruzhki of radical workers through the 1880 s and 1890 s and, in some cases, even into the twentieth century. Tsarist police and judicial records attest to the persistent popularity of a small number of such works, which were used for propaganda among workers by narodovol'tsy (adherents of the populist People's Will Party), social democrats, and socialist revolutionaries. Close study of propaganda among workers in the $1880 \mathrm{~s}$ and the first half of the 1890s indicates that three of these works were particularly successful: (1) The Clever Trick (Khitraia mekhanika), written by the economist V. E. Varzar and originally published on the Vpered! press in 1874; (2) The Tale of Four Brothers (Gde luchshe? Skazka o chetyrekh brat'iakh $i$ ob ikh prikliucheniiakh-usually known as Skazka o chetyrekh brat'iakh), written by Lev Tikhomirov, with a revised and more revolutionary ending by Petr Kropotkin (both members of the "literary committee" of the Chaikovsky circle), and printed by the chaikovtsy in 1873; and (3) less well known, but (according to my evidence) still rather popular, On Truth and Falsehood ( $O$ pravde $i$ krivde), by S. M. StepniakKravchinskii, printed on the Rabotnik press in 1875 . (Kravchinskii had also been a member of the "literary committee" of the chaikovtsy.) These three stories went 
through numerous editions in various formats: printed, hectographed, lithographed, and handwritten, by groups in various cities and towns of the Russian Empire. In the initial, printed editions of the 1870 s, pains were taken to mask their true identity with misleading covers, false publication information (including censorship approval), and sometimes with other titles. (On Truth and Falsehood, for example, had an expanded title that suggested a religious tract: Sermon on Good Friday of the Right Reverend Tikhon Zadonskii, Bishop of Voronezh. On Truth and Falsehood. Another pamphlet was given the ambiguous title: Out of the Frying Pan and Into the Fire! Or, Here's a Fine Kettle of Fish! Not a Fairy Tale, But an Actual True Story of Our Time.)

By the 1880s, the skazka was just one genre in a growing corpus of propaganda literature, alongside poetry, lessons in political economy, biographies of the heroic martyrs of the People's Will, translated novels such as Emma by the German Lassallean Jean Baptiste von Schweitzer, and other forms. In recollections by intelligentsia propagandists from this period, skazki are frequently mentioned in listings of literature used for propaganda, usually with an almost formulaic collective reference, for example: "We read the workers . . . the brochures of the seventies"; "not to mention the old popular brochures 'The Clever Trick,' 'Tale of Four Brothers,' etc"; "Of course we also used the popular-agitational revolutionary literature of that time, for example, 'The Clever Trick'. " 8 Numerous references to and evidence of the use of these tales exists, as well as commentary on their popularity with workers. (Some of the more educated and politicized workers may not have been satisfied with them, but they tended in any case to read the same works of "tendentious" literature being read by young members of the intelligentsia at the time.)

The appeal of the skazki to an audience of urban workers raises several questions for further investigation: How did this peasant-oriented literature transfer to workers? What was the role of the propagandist in this process? Is the peasant/worker distinction even an important one? We also need to know more about other kinds of literature that workers were familiar with: What was the circulation and readership of the cheap publications of lubochnaia literature and, toward the end 
of the century, the newer popular newspapers and illustrated magazines? ${ }^{9}$ Workers also read religious literature and were exposed to other kinds of works in schools.

How was the revolutionary tale told, and what ideas did it present? One that stood the test of time was The Tale of Four Brothers, a story that led Moiseenko to question his beliefs about the world and society. Although the tale was originally used for propaganda among both workers and peasants in the 1870s, archival and memoir material show that it continued to be used among urban workers through the 1880 s and into the 1890s. It was reproduced and distributed by local narodovol 'tsy in Moscow, Odessa, Kishinev, St. Petersburg, and elsewhere; eighty-five copies were seized when police discovered the press that Narodnaia Volia had managed to set up in Taganrog in 1886 . This skazka was also read avidly by workers associated with the early social democratic Tochisskii group in St. Petersburg in the mid-1880s, and it continued to circulate among social democratic workers in the capital in the early 1890 s. $^{10}$

Beginning with the title and opening lines, the reader/listener is drawn by the story form to learn about the brothers and their adventures. The unnamed narrator's "I" intrudes into the story only twice, once in the first paragraph: "No one knows when exactly, but not very long ago; no one knows where, but they say that once upon a time in Mother Russia there lived four brothers." They lived in the "dense" forest (dremuchii les) of fairy tales and "had never seen another human face." "How did they turn up in the forest?" the narrator asks, "I must confess, I never heard anything about that." ${ }^{11}$ One day the brothers get lost chasing a bear and end up on a mountaintop from which they see an inhabited valley spread out below them. Surely life must be wonderful for such a large group of people living together. Their curiosity aroused, they decide to leave their beloved forest home. "Bowing in all four directions," the brothers set out on the quest so central to folktales-but in this case with four, rather than the usual three brothers, parting to travel to the north, south, east, and west. The action that takes place in this introduction, as well as in the incidents that follow, is heavily embellished with detail. Long passages are presented 
in the form of conversations or dialogue, with use of colloquial language and appropriate folk sayings or proverbs, the repository of popular wisdom.

The oldest brother, Ivan, goes north and begins his adventures among peasants engaged in back-breaking field work, while the well-dressed landowner yells orders and then goes off in his carriage. "Do you like that man so much that you do all his work for him?" Ivan asks. (The brothers' naiveté allows them to pose basic questions that get at the root of the relations of power and exploitation in the peasants' lives.) The landholding arrangement and the concept of profit are explained. In the end, the peasants explain, they are forced to work for the landowner out of fear of military reprisals. This section of the tale also includes Ivan's conversation with a landowner in a different village, where he figures out the rule of thumb that the rich can throw their weight around and the poor have to put up with it; a conversation in a tavern that explains why the tsar's emancipation was a disaster for the peasants; and an incident in which Ivan overhears the headman and the butcher plotting to get livestock from the peasants of another locale by collecting taxes early and forcing them to sell their cows. Ivan reveals the conspiracy, but the peasants are afraid to fight those in power. The policeman soon arrives, summoned by the headman. He arrests Ivan as an instigator; Ivan is jailed and soon sentenced for rebellion to Siberia.

Each set of adventures includes multiple incidents and touches on several different topics, with emphasis on the oppressiveness and wrongdoing of the rich, and powerful: landowners, village police, merchants, priests, mediators, factory owners and foremen, even the tsar. The second brother, Stepan, travels south, hoping to figure out why peasants let the rich rob them. He finds himself at a village meeting, where the mediator is trying to get the peasants to agree to move to a piece of land that is sandy, rocky, and completely unsuitable for cultivation. The peasants refuse: they'll die either way. Soldiers are summoned and a bloody conflict ensues. The soldiers of course are peasants too; tragically, one soldier shoots an old man who happens to be his father. Stepan goes to other villages and tries to rouse the peasants to fight back against their oppressors. The narod must stop being its own enemy; all 
the villages, all of Russia, must rise at the same time. The upshot of Stepan's experiences: the peasants of the first village are forcibly relocated to the unsuitable land; Stepan is arrested, jailed, and sentenced to Siberian exile.

Dem'ian, the third brother, experiences and investigates the plight of the worker. He learns at firsthand how manufacturers make a profit at the workers' expense and hears a brief history lesson from "knowledgeable people" (an oblique reference to radical intelligenty) which explains how Russian society got this way, beginning with a society of free, landowning peasants, then moving on to the rule of the Tatars, the rise of the Moscow princes, the rule of the tsar, and serfdom. Again there is a vignette of peasants forced to sell their livestock to pay taxes, this time with a priest exhorting them to do their duty and "render unto Caesar." Dem'ian's arrest follows.

Luka, the youngest brother, explores the true nature of the church more thoroughly. He decides to go to a monastery to see "how good people live." He suffers total disillusionment at the corruption and venality he finds. The "tears" of the wonder-working icon are mechanically produced; the holy relics are made of wax; and the "cures" are faked. Luka tries to tell the people who came to the monastery on pilgrimage about this trickery; arrest and Siberian exile are the foregone conclusion. ${ }^{12}$

The last section of the tale takes place at the boundary between Russia and Siberia; several parties of convicts meet, and the brothers are reunited. They review their findings: there is no place good for the poor. But the day will come, Ivan prophesies, when the narod, sleeping like the "bewitched hero of the fairy tale, " will awaken in all its strength and avenge itself on its enemies, whom he enumerates. $\mathrm{He}$ ends on a utopian note: "Happy will be that wonderful time, when there will be no evil on the earth, no injustice, no oppression, no violence." The earth, forest, and meadows will belong to the peasants, the factories in the towns to workers; there will be no tsars, landowners, or other oppressors. The concluding lines of the tale call for justice and vengeance in an apocalyptic uprising. That night the brothers escape and go forth to spread the word throughout Russia, calling the peasants to a "bloody 
feast." At long last the people will heed the call, and then Mother Russia will roar like the sea and drown all her enemies "in her powerful waves." 13

What made the Tale of Four Brothers an effective work of propaganda? At this point in the analysis, we must engage in some speculation. Although the tale is frequently mentioned in memoir literature and other sources, I have not come across an explicit discussion by a worker or propagandist of its impact. (Moiseenko does, however, include a detail in his memoirs that underlines the impact this tale had on him. He and other worker radicals were quite inventive in their propaganda techniques at the New Cotton-Spinning Factory in St. Petersburg in 1877; they included in their repertoire improvisational performances of Four Brothers. $)^{14}$ What comes through most strongly in this illegal work, its core, is the revelation of the real situation of the narod. The tale explicitly draws back the curtain of official explanation to reveal the pervasive exploitation and oppression of the common people and to name those responsible. The booklet points the finger at the people's enemies: the landowners, priests, bosses, merchants, police, mediators, even the tsar himself. It claims to present the truth. Throughout, the theme of strength in unity is emphasized. Once the narod realize their power, all villages, the whole land would combine forces: they will then be strong enough to destroy their oppressors. In general, the themes and explanations of this pamphlet are echoed in other skazki written during the $1870 \mathrm{~s}$. The means and goals of the popular uprising are treated only briefly in the conclusion: violent popular revolution, and a society where the land and factories are held in common, by the workers. (The term socialism is not used. Some of the other tales go into much more detail on the nature of the desired society.) The form of this work also has much in common with that of other works in this genre: much of the tale is told in dialogue form, with numerous questions and answers. In this way, it served the function of teaching workers how to carry on discussions with other workers, how to answer basic questions.

Interestingly, the revolutionary tale, of all genres of propaganda literature the one that seems the most elementary and naive, continued to be chosen, although less and less frequently, by those composing underground literature at least into the early 
twentieth century. Two of these later skazki - Falsehood Goes on Strike and Dream on the Eve of May First - were used in propaganda among urban workers in 18981900. Both were written by Ekaterina Kuskova, at that time a Social Democrat, and published (without indicating the author) by the Union of Russian Social Democrats Abroad in $1898 .{ }^{15}$ In the first, subtitled, "a fairy tale," Falsehood is depicted as an old woman who now repents of past misdeeds and wants to do something good for humankind. A worker explains to her the concept of going on strike, and suddenly everyone starts speaking the truth, up to the tsar himself. Workers demand and obtain their rights, and Falsehood dies. The second tale, ends on a more pessimistic note. This "true tale" [skazka-pravda] as it is called, tells a more realistic story of workers planning for a secret May First celebration. A Belgian worker contrasts the public May First demonstrations in his own country, and the central character has a dream in which he is transported to Belgium and sees at firsthand how workers live in this freer western country. He is rudely awakened, however, by the police who have come to arrest him; the compromising May First proclamations are in plain view. These two tales were used in propaganda among workers by Social Democrats in Kiev, Moscow, Ekaterinoslav, and Ivanovo-Voznesensk. ${ }^{16}$

Propaganda literature, including $s k a z k i$, played a major role in the formation of a revolutionary identity among those workers who became involved in the movement. It presented new knowledge and a new way to make sense of society, opposed to the teachings of official Russia: the government and government sponsored cultural/educational activities, the Orthodox Church. Illegal literature could avoid the oblique hints of Aesopian language used to circumvent the censorship. While the explanation of the propagandist was especially necessary for a "revolutionary" interpretation of works of legal literature, illegal pamphlets could be and were read by workers on their own. In their plain language, they could tell the truth (from the perspective of the revolutionary movement) about society, point the finger in the face of the people's oppressors, use shockingly strong language, literally curse those in authority. These works had the power of free speech and embodied the ideals of the revolutionary movement. Workers were well aware of the risks involved 
in mere physical contact with these little booklets. To possess, read or circulate them was grounds for punishment and exile. This particular genre seems to have derived some of its power from the narrative story line, intended to draw the reader into the adventures of its characters, who were common people like themselves. The tales may also have served as a link with the real or imagined past of the narod, immortalized in the numerous tales workers had heard and read since childhood.

\author{
APPENDIX \\ WHERE IS IT BETTER? \\ A TALE OF FOUR BROTHERS AND THEIR ADVENTURES ${ }^{17}$
}

This story you should read, And to its words pay heed!

\title{
In the Forest
}

No one knows when exactly, but not very long ago; no one knows where, but they say that once upon a time in Mother Russia there lived four brothers: Ivan, Stepan, Dem'ian, and Luka. From childhood until they were completely grown they lived in a dense forest and never saw another human face. How did they turn up in the forest? I must confess, I never heard anything about that.

The four brothers lived in harmony, loved each other, helped one another, and any one of them would have gone hungry so that their brother would have food to eat. They built themselves a little cottage in the forest, and every day one brother would stay home and do the housekeeping while the other three went into the forest 
to hunt. Living thus in friendship and harmony, the brothers knew neither want nor sorrow; they didn't know luxury, either, but in truth they didn't miss it.

Since the brothers had lived in the forest from their earliest years, they had no idea if there were other people in the world beside themselves. They assumed that there were, but how these people lived they didn't know, and they didn't bother themselves about it either.

But one day when three of the brothers went hunting they came across a bear. They see that Mishka [the bear] has a fine fur coat. Why not kill the bear for it? The bear takes to his heels, the brothers are right after him, and they chase him nearly the whole day. But try as they might, the confounded beast would not give himself up. Finally they reached a tall mountain. The bear went up the mountain and hid in the forest (that mountain was all overgrown with forest). The brothers see they don't have the strength to chase him up the mountain; they're very tired. They were sorry and vexed to let the animal go, but there was nothing to do about it, it was already time to turn homeward; evening had come.

But although the brothers just wanted to go home, none of them knew which direction to go. Running after the bear all day, they'd lost their way. The brothers thought about it and decided to send Ivan up the mountain: if he climbed to the top and took a look around, maybe their way would be visible. Ivan agreed, went up the high mountain, and in a minute was already hidden in the forest.

The brothers waited and waited, but Ivan didn't return. The brothers began to worry that some misfortune had befallen him and sent Stepan up the mountain to look for Ivan and catch sight of their route. Dem'ian waited below. He waited an hour, then another; no brothers appeared. Dem'ian got frightened and climbed up the mountain himself.

He climbed right up to the top-no sign of his brothers. And he really yelled and called them. No, it was as if they'd vanished into thin air. Then Dem'ian began to cry and climbed a tree to take a look for the way home. He peered down from above-and saw a wonderful sight. The forest ended not far beyond the mountain, and further lay a broad plain, without end or border. And on that plain were several 
settlements and villages. You could see fields and meadows where cattle grazed; on the roads, carts and people traveled. Dem'ian saw that there were many of these people. In the distance a town was barely visible, with houses of white stone three stories high, with tall churches, and the sun shone brightly on their gilded cupolas. That's what Dem'ian saw from the top of the tree. Never had he thought that there were so many people, so many villages; never had he seen such beautiful white houses and gold-domed churches. All of this very much amazed him, and he gazed until the sun went down and night was coming on.

"How wonderful!" he breathed.

"Really wonderful," echoed someone from another tree.

"Really and truly wonderful!" said someone from a third tree.

Dem'ian looks around-and sees his brothers sitting in the trees. It turned out that they were so lost in contemplation that they didn't even hear when he was yelling and calling for them. The brothers rejoiced and went home, since the view from above had clearly shown them their way.

As the brothers went, they talked about what they had seen from the mountain.

"You see, brothers," said Ivan, "That must be where people live as in paradise. There are a lot of them, so they would have the resources to do anything. If they need to fell trees or drain a swamp, or lay down a road, or build buildings of white stone, they can do it, because many of them live together and they have a lot of strength. But the four of us living together, what can we do? Nothing. We don't live any better than some bear. That's the real truth. And what if someone gets sick? There are many of them and some will always be healthy, but we-remember when a bear mauled me and brother Luka was taken ill with a fever? We nearly died of hunger. There's no doubt about it: it's better by far when a lot of people live together, and more cheerful and prosperous."

"So, brothers," said Stepan, "why don't we leave the forest and take a look at people and show ourselves? Then we'll really begin to live! We'll be living off the fat of the land! That's enough of living in the forest." 
"So let's leave," the brothers agreed.

They arrived home and told their younger brother everything they had seen and decided to leave the forest on the very next day.

No sooner said than done. They dressed in their best clothes, took provisions for several days, bowed in all four directions, and left their native forest. After two days they reached a level area and went along a country road; on both sides golden rye rustled, and the brothers were happy and lighthearted.

Suddenly they heard the rumble of wheels. A miserable little cart was going by to which was harnessed a wretched little horse, and on the cart sat a poor peasant-thin, pale, and ragged.

"Hello, good man," said the brothers.

"Hello," he answered. "What brings you to these parts?"

The brothers told him where they were from and why they had come.

The peasant shook his beard and said, "You've come in vain, my dears, in vain. You'd have been better off staying in your forest, never knowing the blessing of master or police officer. Now you'll know sorrow!"

The brothers were frightened. "Tell us sensibly, Grandpa, why would it be better for us to stay in the forest?"

"What's the point of frightening people? I don't have time to explain it to you, my dears. But I tell you: return to the forest. It'll be better."

With that, the old man went on. The brothers paused and began to discuss whether the old man had told them the truth or lied to them. They thought and thought and decided he must have lied, because how could it be bad to live here? Plenty of land, a lot of people, and besides, if it's bad to live here, would people have built such mansions as they had recently seen from the mountain? No, truly the old man must have lied.

The brothers went further. They saw a wanderer going by singing a song, such a mournful one, that the brothers began to listen:

I go by the meadows; the wind whistles in the meadows: 
It's cold, little wanderer, it's cold;

It's cold, my dear one, it's cold.

I walk through the grain-why are you so meager, grain?

From the cold, wanderer, from the cold;

From the cold, my dear one, from the cold.

I pass by herds--why are the cattle so weak?

From hunger, wanderer, from hunger;

From hunger, my dear one, from hunger.

I go into a village: $m u z h i k,{ }^{18}$ do you live warmly?

No, I'm cold, my dear one, cold;

Cold, my dear one, I'm cold.

I go to another village: muzhik, is your belly full?

No, I'm hungry, little wanderer, I'm hungry;

Hungry, my dear one, hungry.

And a third I visit: peasant, why do you beat your woman?

From cold, wanderer, from cold;

From cold, my dear one, from cold.

And a fourth: muzhik, why do you go to the tavern?

From hunger, wanderer, from hunger;

From hunger, my dear one, from hunger.

I traveled throughout Russia: the peasant moans and groans,

He moans from the cold, from the cold;

He groans from hunger, from hunger. ${ }^{19}$

The wanderer passed by, and the brothers stood, still listening to the plaintive song. "Well brothers, they don't sing songs like that where the living is good. Clearly, was the old man telling the truth?"

"Clearly, he didn't lie," said Stepan.

"What to do now?" asked the third brother.

"Search for where it is better," said the fourth. 
And the brothers decided to go looking for a place where it is good to live. One would go north, one south, the third to the east, and the fourth to the west. And then they'd meet up and go together to the best place. The brothers bid each other farewell and parted.

\section{In the North}

Ivan, the oldest brother, went north and soon came to a village. He sees peasant men and women working in the field. The sun is scorching; they're dripping with sweat. And among them walks the master [barin] in a straw hat and foreignstyle suit, with a walking stick in his hands. He walks around and doesn't do anything himself, just, you know, shouts at the peasants. After a while he says, "Phew, it's so hot in the field, I'm exhausted," and he gets into his carriage and leaves.

Ivan approaches the peasants and asks, "Tell me, gentlemen, who is that who just left?"

"That's our master," they answered him.

"Master? So . . . But why, allow me to ask, do you work like this, and that guy doesn't do anything, but has just gone off in a carriage? And he's dressed better than you, and he's so delicate: just look, it's hot, so he's stopped doing anything. I suppose it's not too hot for you to work? Tell me, peasant sirs, where did he get such privileges? Do you love him so much, or is it something else?"

At first the peasants just laughed at Ivan's words; they thought, this guy is just kidding around. But then Ivan explained that he had lived his whole life in the forest and didn't know any of their customs.

Then the peasants began to explain to him: "You see, this is why the master is privileged: all this land belongs to him. We don't have much land. So the peasant goes to the landowner and gets hired to work; for his work he is paid a small 
amount, and the whole harvest goes to the landowner. It turns out that the master pays all the workers together about one hundred rubles. But the landowner gets two or three thousand rubles from the merchant for the wheat or rye which the peasants sowed, cultivated, and harvested. So then that's his profit. He didn't lift a finger, but, you see, he caught one or two thousand rubles. Understand? Somewhere else he might even get three thousand, if he has a lot of land. So God knows how many thousands are collecting in the landlord's pocket, even though he doesn't do anything. Sometimes the peasant agrees on a sharecropping arrangement with the landowner; again, the landowner doesn't do anything, but ends up with half of what the peasant earned. There are many peasants-and the landowner gets about as much as they do all together. That's why he can do nothing, why he has better clothes, why he lives so well."

Ivan listened and listened, and then said: "So then the whole reason is that the land belongs to the barin. But, fellows, that's certainly a lie. The land is God's, just the same as the water, the air, the sun, or the stars. If I tell you that the sun is mine, are you going to pay me money so that it will shine? Of course you won't! So why do you pay for the land?"

"Brother," said the peasants, "we know that without your help. But you see, if we don't pay the landowner money, or if we take it into our heads to sow grain on his land without permission, soldiers will come with guns and cannon, they'll begin to shoot, stab, and rob us, so we submit whether we want to or not."

Just then the bailiff came up and chased Ivan away, so that he wouldn't hinder the work.

Ivan went on to the village itself. Such poverty there-it was terrible. Tumbledown huts, barely standing. Farm equipment-not a thing to their name. It makes one sick at heart. Inside the huts it's even worse: filth, stench, kids crying, asking for something to eat. . . . Ivan also began to cry, it was all so unfamiliar. Near the village he saw the landowner's estate: a two-story stone house with an iron roof painted green, a cast-iron balcony. Around the house were flower beds of rare flowers. Near the house were various structures of a wealthy estate; there were also 
horses, pigs, and all kinds of fowl. The landowner himself sat on the balcony in a dressing gown, smoking a pipe and drinking coffee.

Ivan was annoyed and in his own simple way spoke to the landowner: "Sir, please tell me, why do those peasants live so poorly?"

The landlord looked at him angrily and answered: "Your muzhiki are drunkards and lazybones. If they worked, they wouldn't live in such poverty."

"Is that so, barin? How is it that you do nothing, and just look at your estate. Those peasants are working in the field, and you sit there drinking coffee. No, Sir, the muzhik isn't poor because of laziness, but because you take everything that he earns. Work as much as you like, but you won't manage to get out of poverty. That's not right, you know, barin!"

Ivan didn't say this to insult the landowner, but because he thought, in his simplicity, to appeal to his conscience. Ivan didn't know yet that a rich man's conscience is like hardened steel; there's no way to soften it. Ivan said this from the goodness of his heart, but the landowner became angry.

"How dare you, with your ugly peasant mug, speak to me so rudely," he shouted. And you're in for it now, you son of a bitch, you rabble-rouser [buntovshchik]! Hey, Van'ka, Mishka! Take this fool to the district police officer [stanovoi]: maybe he'll teach him some manners."

They took Ivan off to the police officer, but the landowner was unable to calm down for a long time. He kept repeating: "What people, ${ }^{20}$ good Lord, what people! Wild beasts! They don't let you drink a cup of coffee in peace."

The police officer did a fine job of teaching Ivan; he gave him a good beating, as much as he felt like. He beat him and kept repeating: "Don't be impertinent, scoundrel, don't you dare say anything to your betters. Be humble before the rich man. Remember, fool, once and for all: don't fight with the strong and don't take the rich man to court. Know the law, know the custom."

He pounded Ivan for a long time and kept repeating these things. Finally Ivan understood that the law consisted of the rich man bullying the poor man, while the poor man was supposed to take it all quietly and get down on his knees. 
The police officer finally let Ivan go in peace, and Ivan left that village without a backward glance. "Here they'll skin the hide right off you," he thought. He soon came to another village. But here he again saw the same thing: again the peasants worked and lived in poverty, and the landowner didn't do anything and lived in wealth. He went further. He went on for some time. Finally he got tired and wanted to eat. "It would be good to rest now," he thought, and just then he saw a tavern by the road. He sees people going in and out, eating, drinking tea. Ivan went in too.

"Give me vodka and something to eat," he said to the owner.

"Do you have money?"

"Money? No, I confess."

The tavernkeeper laughed: "What do you mean, you want it without money? Very clever, brother, but that's not the custom here. Here's what you should do: sell me your fur coat, and then with that money you can eat and drink. Well then, I'll give you a ruble."

Ivan had a coat of sable; he caught the animal himself in the forest, and the coat was worth more than one silver ruble, but Ivan, lacking experience, didn't know anything about this. By chance he knew about vodka-on the road a passerby had treated him.

"O.K.," he said, "a ruble then." He took off the coat and took the ruble. The tavernkeeper even exclaimed, "The Lord really sent a fool!" He was even somewhat ashamed, and gave Ivan half a glass for free.

Ivan sat, drank vodka, and had some refreshment. A ragged fellow was sitting there too, not eating or drinking, just watching the others. Obviously his belly had brought him, too. Ivan noticed him and said:

"Uncle, hey uncle!"

"What do you want?" answered the muzhik.

"Don't you want to drink and eat a little? It'll be more cheerful together."

The peasant drank, ate, and he and Ivan began a conversation. Well first, as people do, they got acquainted, introduced themselves, then the peasant asked Ivan 
where he was from and where he was going, and why. Ivan answered, well, he says, thus and thus, I come from the forest and I'm searching for where it is better to live. My brothers, he says, went, one to the south, another to the west, a third to the east, and I ended up going north. The peasant listened and burst into laughter.

"Oh, you've amused me, Ivan, really, that's the truth! What eccentrics! Right from the forest. Listen, friend, go to the south or anywhere you like, it's all the same. Don't bother searching for the place where the peasant lives well! Believe me, I've been around. And judge for yourself: how can the peasant live well? Judge for yourself."

"Why can't he live well?" asked Ivan.

"Oh, you're such a fool, old chap! What foolishness you're talking. Think about it. In the first place, does the peasant have land?"

"I don't know."

"You don't know? Well then, I'll tell you. He doesn't have his dear land [zemlitsa]. He has the tiniest bit, and it's the most worthless, low-grade land. That's what! I see you don't know anything, so I'll tell you. We used to belong to the landowners, we were serfs, understand? We belonged to them body and soul. In those days the son-of-a-bitch would say: I have one hundred or five hundred souls. And his own soul was long ago sold to the devil, truly! Well then, in '61, 19 February, the tsar freed us. Wait, you don't even know who the tsar is? The tsar, old man, is in charge of all the earth, there's no one higher than him, he does what he wants, and there's no law written for him."

"Where does he come from? Was he chosen, perhaps?"

"What do you mean, chosen? He was just born from his father. His father was tsar, so he's tsar."

"I see you have some strange customs!"

"Really strange, brother! But that's not the oddest thing about it. Listen a bit more. When we were serfs, we endured terrible torments from our lords, and we had only one hope-in the tsar. We had complete faith in him. We thought perhaps he, our little father [batiushka], would take pity on us and free us from this torment, 
would give us our beloved land. And what do you think? He freed us all right-but he freed us in a way you wouldn't wish on your enemy, that's how. In the first place: they designated from among our landowners, our evildoers, you hear, they designated arbitrators, ${ }^{21}$ who could decide which land should go to us, and which should remain with the landowners. And they decided: they allotted us sand, stone, and swamp. And they didn't give us the land free of charge, but for money, and a lot of money at that. Figure out everywhere how much the land is worth, and that's how much they took from us. And if the peasants didn't agree, those arbitrators immediately called the soldiers, who began to shoot with guns, cannon . . . catastrophe: like it or not, you have to take the land, even if it's not worth a penny [grosh]."

They each drank another glass. Then Ivan asked: "Well, if the landowner hadn't agreed to give you the land, would they have sent soldiers against him?"

"What do you mean! No way, they'd never send them."

"So then everything's done to the benefit of the lords?"

"Yes, everything for them! Now listen further. They gave us some land, they freed us. We were free, well then, go where you want: to jail, to Siberia, or to the grave-you can go anywhere. We started life afresh, but it has turned out badly. There's not enough land, it's worthless, nothing grows. And taxes are even more than before: for the land alone there's the redemption fee, and the poll tax has become four times greater! It turns out that you have to go to the same old landowner and get hired by him, because you've got to get money from somewhere. And the peasant still needs grain, hay, and firewood. And we don't have much plough land, even less meadow, and no forest at all. So you go to the landowner and get some land to sharecrop, or you rent some. And we fell into slavery even worse than before. Whatever you do, right away there's a fine. As they say: They used to beat you with a cudgel, and now they do it with a ruble. Eh, what a life we have, Lord forgive me!"

They drank some more. They were silent, and then the muzhik again began to speak. "So you see, my dear man, there's no way for the peasant to live well. 
Taxes alone increase from year to year. And there's no money-they sell your last cow to pay the arrears. Then they start beating people. At the slightest excuse they immediately send soldiers-they shoot, they kill. Disaster!"

"But tell me, Uncle," asked Ivan, "where do they get their soldiers?"

"My dear man, they're from us, from us."

"How from you?"

"Rather, from the peasants. They take our sons, our brothers, train them for the military, and then send them against us. And they beat their fathers and brothers to death. What a terrible thing!"

"Your ways sure are strange. You mean, you kill your own?"

"Yes, dear one, our own. An outsider can't believe it, but it's true: our own."

Ivan went on and saw that the muzhik had told him the truth, the honest to goodness truth. He traveled through many villages and towns-everywhere there was grief for the peasant and worker. Ivan got mad and thought about turning back, when he finally happened on one little village. He got closer and saw two men traveling in a cart, heatedly discussing something. The horse was going slowly, and Ivan soon caught up with the cart and heard the conversation.

"So you keep your word, Nikita Ivanovich: pressure them to pay their taxes in such a way that they won't be able to manage it. Put their livestock up for sale first of all, and I'll be right there to buy the cattle for a song. Hee, hee, hee, it's really clever! And I won't forget you, Nikita Ivanych, your ten percent."

"O.K., O.K., what are you pestering me for? I said it, well I'll do it," answered the other.

Ivan overtook the cart and came to the village. There he met a peasant.

"Who's that there in the cart?" he asked him.

"That's our starshina, ${ }^{22}$ said the peasant, "with the butcher from the town."

Ivan guessed what was going on. "Just wait, bloodsuckers," he said to himself," I'll blow the whistle on you!" 
The headman and the butcher arrived. The butcher went into a hut, and the starshina went and called a meeting. ${ }^{23}$ The peasants gathered: "What's up?"

The headman began to demand money, taxes. The peasants answered, "Wait a little, Nikita Ivanovich, let us sell our grain. Then we'll pay in full."

The headman insisted, "No," he said, "I can't delay one second. I'm not my own master either. If you don't have money, I'm going to inventory your livestock!"

"Have you no heart, Nikita Ivanych, that you want to ruin us completely? Wait a bit. We'll pay everything like we're supposed to."

"No more talk!" shouted Nikita Ivanych and began to seize the livestock. The butcher suddenly appeared, "Pray, do you wish to sell your livestock?" he asked.

"I'm selling," said the starshina, "what about it?"

"I'd buy, if the price is right."

They spoke in this manner, and didn't let on that they'd already made a deal.

"Well then, buy!" answered the headman. And he began to price the cattle: this cow is worth thirty rubles, he'll let it go for three. It's terrible, what kind of business is this!

Ivan couldn't stand it, he stepped forward and said: "Listen, Christians, ${ }^{24}$ here's what I heard these swindlers, your headman and the butcher say." And he told them everything-how they had reached an agreement and how the butcher promised to share the profits.

My dear fellows! As he was telling all this, the peasants got very angry and started to curse the headman as a Jew and exploiter, ${ }^{25}$ and the latter began to snarl. One thing led to another, and the peasants began to strike the headman, shouting, "Don't sell the mir!"26 Ivan also grabbed Nikita Ivanych and almost pulled out his whole beard. The headman finally broke loose, jumped on his horse, and fled the village. The peasants wanted to go after him and grab the butcher too, but they couldn't do it-he was already long gone.

"Why do you keep such a swindler as a headman?" asked Ivan.

"Who's keeping him?"

"Well then, you must have chosen him?" 
"Eh, my dear man, it wasn't us. He chose himself!"

"How's that?"

"Here's how. At the last elections we wanted someone else instead, but he learned about this and chose only his friends for the meeting, the same kind of swindlers as himself - and made himself headman again! And he even makes fun of us. 'You fools,' he says, 'you think you're going to push me aside, I'll be your boss for a lifetime.' And that's how it was. We lodged a complaint against him."

"Why a complaint? You should have fired him, and that's the end of it."

"No, my dear man, it's the law. By ourselves, without the law, we're not allowed to do anything-the consequences would be severe. That is to say, they don't care a rap about us-but it seems that even then you can't do anything without the law. And you say fire the starshina. You need to write a complaint. And we did write one and gave it to the arbitrator. So what happened? The headman, that is Nikita Ivanov, is no fool either, and he's friends with the arbitrator; whenever there's some holiday or name day he goes right away to congratulate him, brings a little present, even gives the arbitrator's wife a little gift, and something for their children. So the arbitrator thinks the world of him. He read our complaint, came and cussed out the whole commune, and left. We made another complaint-this time, then, to the conference [ $\left.s^{\prime} e z d\right]$, as the law requires. And at the conference there sits our arbitrator again, and various friends of his, and nobles he knows. They didn't give us any satisfaction here either. We made a third complaint, again in a lawful manner, to the provincial bureau. And at the bureau, there again were the same relatives and acquaintances of the same arbitrators who had rejected our complaint at the conference. And for that reason they didn't do anything for us there, either. So it turned out that the arbitrator came to us. 'You so-and-so's,' he said, 'took it into your heads to make trouble!' He flogged just about the whole village. 'If you don't settle down,' he said, 'you won't escape Siberia, you rascals!'

"We thought and thought and sent an emissary to Moscow to the best lawyer to ask, well then, what should we do? The lawyer considered our case, thought, looked at the law. 'Fellows,' he said, 'it's impossible to do anything for you. The 
law is against you. The law is so constructed that the authorities can do anything they want, and according to the law the muzhik must suffer everything in silence.' He explained the whole law to us. We saw that there's nothing to be done. So from that time we gave it up as a lost cause!"

"You should have driven him away in spite of the law," said Ivan. "What the devil do you need the law for!"

"Well, then the soldiers will come and start to shoot and rob."

"But you peasants are a hundred times more numerous than the soldiers, aren't you? What are you afraid of?"

"That's all well and good, but still. If someone took the first step, we wouldn't sit around twiddling our thumbs. But everyone's afraid to be first."

"Oh, truly, you're spineless creatures, and not muzhiki. They don't beat you enough!"

The next day the district police officer came with witnesses. The headman declared that the peasants were rioting and that the main instigator was Ivan, the passerby. Well, the police officer immediately seized him, shackled him, and put him in jail. Within a month he was tried and sentenced for rebellion [bunt] to Siberia. 